可視化情報 Vol.16 Suppl. No.1（1996年7月）

\title{
225 抽気を有する超音速キャビティ流れと 斜め衝撃波の干渉
}

佐賀大松尾繁○、ツォイチィウス ミヒャ工ル，瀬戸口俊明， 田中和彦，金子賢二

Interaction between Oblique Shock Wave and Supersonic Cavity Flow with Mass Bleed

Shigeru MATSUO*, Michael ZEUTZIUS*, Toshiaki SETOGUCHI*,

Kazuhiko TANAKA* and Kenji KANEKO*

In recent years, research and development activities for next generation supersonic transport are being carried out actively by the world aeronautical communities. In a supersonic intake, a cavity plays an important role in the control of shock waves. The supersonic intake flow tends to be unstable due to the interaction of shear layer in the cavity with oblique shock waves generated by ramp and cowl on the forebody. In the present study, the effects of cavity/oblique shock wave interaction and bleeding on the pressure oscillation in the cavity were investigated experimentally by a schlieren optical method and pressure measurements in the case of the flow Mach number 1.74 at the cavity entrance.

1.はじめに

次世代超音速・極超音速輸送機の実現の重要な鍵は、エアーブリージングエンジンの開 発である。その構成要素であるインテークは、すべての作動条件で空気を効率的にエンジ ンへ供給する役割があり、衝撃波の安定化や圧力回復性能の改善をはかるためにスロート 部にキャビティを設けて抽気する場合がある(1)。この場合、機体前部のランプとカウル で発生する二つの斜め衝撃波やインテーク内部で生ずる衝撃波は、境界層やキャビティ上 部に存在するせん断層と干渉し、圧力回復性能等に影響を及ぼすことが考えられる(2)。

本研究は、超音速流中に取り付けたキャビティ内の流れの振動特性を明らかにすること を目的とする。本論文では、キャビティ入口マッ八数を約 1.74 の一定とし、まずキャビ ティ前縁角部より生ずるせん断層と斜め衝撃波が干涉する場合の圧力变動を実験的に明ら かにし、ウエーブレット変換 (4) により、キャビティ内部を伝播する波の特性を調べた。 さらに、キャビティ底部からの抽気がキャビティ内の振動へ与える影響について調べた。

2 . 実験装置と方法

本研究で使用した超音速風洞と計測方法は、文献(3) と同じである。図 1 で示すキャビ ティ長さ $L$ とキャビティの高さ $D$ の比 $L / D$ は1と 1.5 である。キャビティ前縁角部より生 ずるせん断層と斜め衝撃波との干涉による振動への影響を調へるために、図中に示す形状 のくさびを上壁に設置した。Xiと 断層への入射位置（原点：キャビティ角部）とキャビティ前縁角部近傍に存在する衝撃波

* Faculty of Science and Engineering, Saga University, 1, Honjo, Saga-shi, Saga, 840, Japan. 
の傾き角を示している。また、干渉による振動現象に及ぼす抽気の効果を明らかにするた めに、キャビティ底部に抽気孔を設け、これを測定部の近くに設置した真空タンクと直結

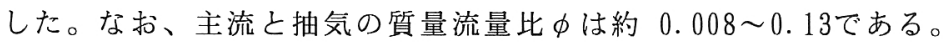

3. 実験結果亡考察

3.1 流れの可視化

図 2 は、 $L=20 \mathrm{~mm}$ 場合に、斜衝撃波のせ ん断層への入射位置 $(X i)$ の変化が流れ場に及 ぼす影響を示すシュリーレン写真である。図よ り、斜め衝撃波とせん断層との干渉により膨張 波が生じ、その影響でせん断層は主流側へ向く のが観察される。

図 3 は、衝撃波の入射位置 $X i$ が $10 \mathrm{~mm}$ で、 ヤビティ底部から抽気がある場合のシュリーレ ン写真である。図より、抽気量（申）の増 加とともに衝撃波角 $\alpha$ は僅かであるが減少 することがわかる。これは、抽気により主 流の質量流量の一部がキャビティに吸い込 まれ、キャビティ内压力が低下することに よるものと考えられる。なお、 $L=30 \mathrm{~mm}$ の場合においても図 $2 、 3$ とほぼ同様な結 果が得られた。

\section{2 斜め衝撃波が振動に及ぼす影響}

図 4 は、Lが20 mm で斜め衝撃波の入射 がない場合とキャビティ入り口角部から $X i$ 0，10，20 mmの位置に斜め衝撃波が入射 する場合に、センサーS1で測定した圧力の 時間変動である。横軸は風洞の持続時間内 の任意の範囲を、縦軸は絶対圧力 $p$ を示し ている。図よりせん断層の成長開始点近傍 に斜め衝撃波が入射する場合、すなわち $X$ i $=0 \mathrm{~mm}$ の場合には、図 4(a) と比較して圧 力変動の振幅が大きくなっているのがわか る。せ九断層の成長開始点近傍に斜め衝撃 波を入射させることは強い乱れを加えるこ とを意味し、これにより振幅が大きくなる ものと考えられる。 $X i=20 \mathrm{~mm}$ の後縁角 部に斜め衝撃波が入射する場合には、 $X \dot{i}$ $0,10 \mathrm{~mm}$ 場合と比べて振幅は小さくなっ

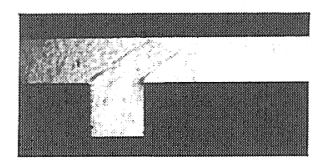

(a) No wedge

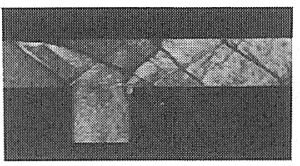

(b) $X_{i}=0 \mathrm{~mm}$

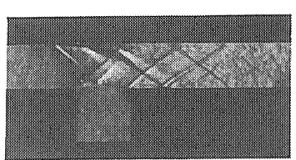

(c) $X_{i}=10 \mathrm{~mm}$

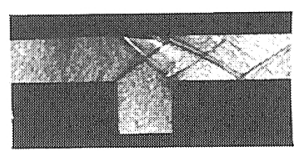

(d) $X_{i}=20 \mathrm{~mm}$

Fig. 2 Schlieren photographs

( $\phi=0, L=20 \mathrm{~mm}$ )

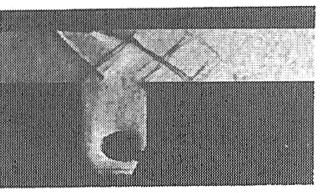

(a) $\phi=0.0078$

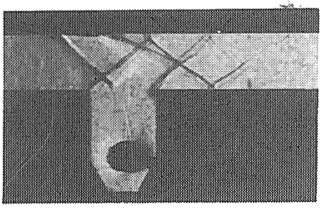

(b) $\phi=0.031$

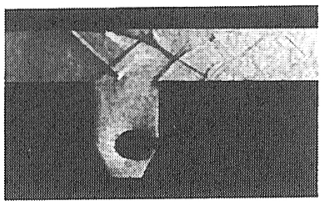

(c) $\phi=0.13$

Fig. 3 Schlieren photographs $\left(X_{i}=10 \mathrm{~mm}\right.$, $L=20 \mathrm{~mm}$ ) 
ているが、これは斜め衝撃波が後縁角部で生ずる衝 撃波と干渉し、直接せん断層に影響を及ぼさないた め上考光られる。

図 5 は、図40圧力波形を基にして得られたパワ 一スペクトル分布を示している。横軸は周波数 $f$ を、 縦軸はパワースペクトル $S$ である。図 5(a) の干渉 がない場合は、約 $7 \mathrm{kHz} こ 21 \mathrm{kHz}$ 付近にピークが観察 される。約 $7 \mathrm{kHz}$ の周波数は、キャビティ長さ $2 L$ を 音波が伝ぱすると仮定した場合に得られる周波数と ほぼ一致しており、さらに約 $21 \mathrm{kHz}$ の周波数はキャ ビティ前縁からの瀜放出によるものと思われる。一 方、 $X i=0 \mathrm{~mm}$ の場合には、くさびからの入射衝撃 波亡キャビティ前縁角部から発生する衝撃波の干渉 に起因すると思われる振動が、約 $20 \mathrm{kHz}$ 付近に観察 される。しかし、Xi=10m 以上ではそれは観察 されない。これは、斜め衝撃波とせん断層の干渉の 効果のために、キャビティ前縁からの渦放出による 振動現象が抑制されるためであると思われる。なお、 $L=30 \mathrm{~mm}$ 場合においても図 4、5とほぼ同様な傾 向が得られた。

図6(a)、(b)は、それぞれ図 2(a)、(b)に対応す る場合の連続ウェーブレット変換（マザーウェーブ レット：Morletのウェーブレット）より得られたウ エーブレット係数（W）の值を色の明暗で示した図 である。図中において色が濃い箇所が、Wの值が大 きいことを表している。なお、縦軸はスケールパラ

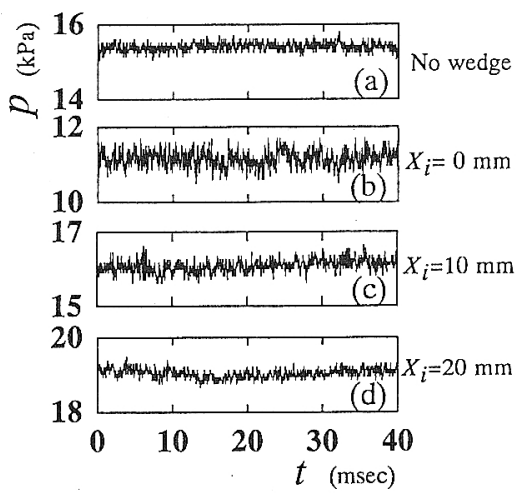

Fig. 4 Pressure time histories ( $\phi=0, L=20 \mathrm{~mm})$

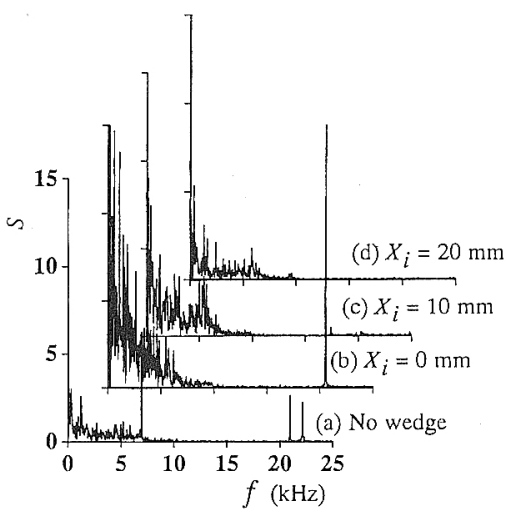

Fig. 5 Power spectrum density distributions

( $\phi=0, L=20 \mathrm{~mm})$

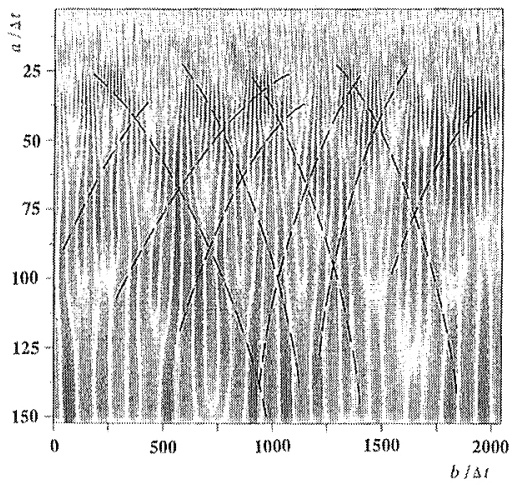

(a) No wedge, $L=20 \mathrm{~mm}$

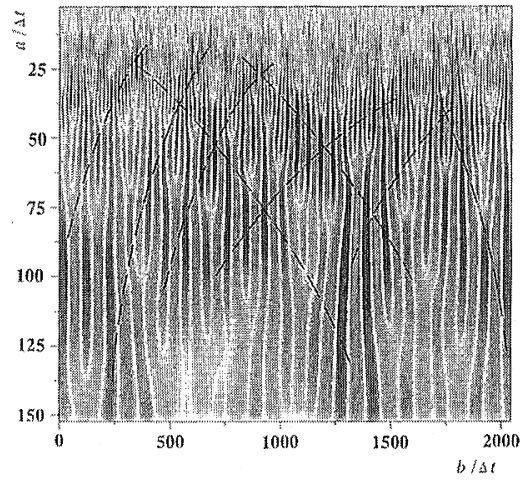

(b) $X_{i}=10 \mathrm{~mm}, L=20 \mathrm{~mm}$

Fig. 6 Wavelet transform of pressure oscillation 
メータ $a$ を、横軸は経過時間 $b$ を示す。また、 $\Delta$ $t(=0.02 \mathrm{msec})$ は、圧力変動の離散化の時間間隔 である。両図より、Wが大きい值は同じスケール の位置においてのみ生じるのではなく、点線で示 すように時間の経過とともに小さなスケールから 大きなスケールへと連続的に変化しているのがわ かる(もしくは、大きなスケールから小さなスケ 一ルへの変化）。また、衝撃波との干渉により $W$ は大きな值を示しているのがわかる（図6(b))。 これらの結果は、 $L=30 \mathrm{~mm}$ 、および $X$ iが 10,20

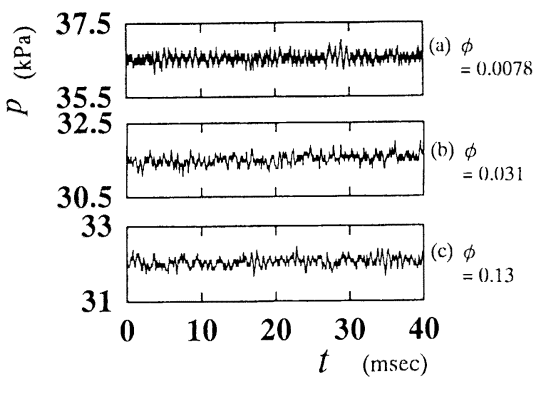

Fig. 7 Pressure time histories $\left(X_{i}=10 \mathrm{~mm}, L=20 \mathrm{~mm}\right)$ mmの場合においてもほぼ同様な傾向が得られた。 3.3 キャビティ抽気が振動に及ぼす影響

図 7 は、 $L$ が20 mm の場合で、キャビティ底部 より抽気がある場合の压力の時間変化を示してい る。なお、計測はキャビティ前縁から $10 \mathrm{~mm}$ 、深さ $20 \mathrm{~mm}$ の位置の㑡壁で行った。抽気行うと、図 4 (c) と比べると振動の振幅は小さくなるのがわかる。

図 8 は、 $L$ が20 mm の場合のスペクトル分布図 を示している。図 8 (a) の抽気量が小さい場合に は、図 5(c) と同様な高周波成分（約 $18 \mathrm{kHz}$ ) が 存在しているが、抽気量が大きくなるとともに高 周波成分は小さくなり低周波成分が増加している のがわかる。なお、図は示していないが、 $L=30$

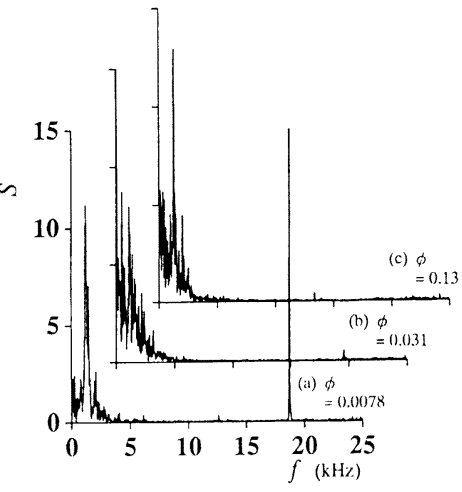

Fig. 8 Power spectrum density distributions $\left(X_{i}=10 \mathrm{~mm}, L=20 \mathrm{~mm}\right)$ mmの場合においても図 $7 、 8$ とほぼ同様な傾向が得られた。これらより、抽気は振動の振 幅および高周波成分の低隇に効果的であることがわかる。

4.まとめ

超音速キャビティ流れと斜め衝撃波の干涉がキャビティ内の振動現象に及ぼす効果を、 キャビティ底部からの抽気の有無に対して実験的に調べた。その結果、せん断層に衝撃波 を干渉させると、その入射位置によって圧力変動の振幅は大きく変化し、特にせん断層の 成長開始点近傍に斜め衝撃波が入射する場合には压力変動に大きな変化が見られた。また、 キャビティ底部からの抽気は、高周波成分及び振動の振幅低減に効果があることを示した。 さらに、ウェーブレット解析の結果から、キャビティ内部にはスケールの大きい波と小さ い波が連続的に伝播していることが明らかになった。 参考文献

(1) Seddon, J. and Goldsmith, E. L., Intake Aerodynamics, (1985), AIAA education series.

（2）村上・ほか6名、第28回飛行機シンポジウム、(1990)、480.

（3）松尾・ほか4名、可視化情報、15-Suppl.-1（1995)、197.

(4) Farge., M., Ann. Rev. Fluid Mech., 24(1992), 357. 